\title{
Impact of FDI, ODA and Migrant Remittances on Economic Growth in Developing Countries: A Systems Approach
}

\begin{abstract}
This paper seeks to investigate the relative contributions of foreign direct investment (FDI), official development assistance (ODA) and migrant remittances to economic growth in developing countries. We use a systems methodology to account for the inherent endogeneities in these relationships. In addition, we also examine the importance of institutions, not only for growth directly, but in the interactions between institutions and the other sources of growth. It is, we believe, the first paper to consider each of these variables together. We find that all sources of foreign capital have a positive and significant impact on growth when institutions are taken into account.
\end{abstract}

Word Count: 10033

Keywords: Growth, FDI, Official Development Assistance, Remittances, Institutions JEL Classification: C33 F24 F43 F35 O43 O24 


\section{Introduction}

With the increased focus in the international community on development within the poorest countries of the world, via the Millennium Development Goals, attention has turned to the relative importance of the various forms of capital flows, and their effectiveness in alleviating poverty.

Overseas capital flows, comprising of foreign direct investment (FDI), official development assistance (ODA) and migrant remittances have grown significantly over the past 20 years. Despite this, economists have never considered the combined impact of each of these variables on economic growth. Our main contribution in this paper is to address this shortcoming using a new approach, while further considering the importance of institutions when determining the relative effectiveness of international capital flows. The literatures on the individual growth impacts of FDI (see for example Lim (2001), and Hansen and Rand (2006)) and foreign aid (see Hansen and Tarp (2001) and Doucouliagos and Paldam (2006)) are relatively well developed. In contrast, the literature which looks at the impact of migrant remittances on growth is more limited. This paper's second key contribution is to build on this limitation.

Our analysis is set within the context of the current debate on the importance of institutions for development. This issue was highlighted by President Obama on his first visit to Africa in 2009. There are strong arguments, based on the analysis of La Porta et al (1997) and Acemoglu (2001) for believing that institutions improve and accelerate development. In much of this literature, (see North (1990) and Landes (1998)) it is argued that European nations achieved prosperity because they embraced institutions that encouraged private initiative and innovation. For this reason, if 
developing countries in Africa, Asia and South America are to experience similar success, they need to adopt institutions in a similar vein.

The remainder of the paper is set out as follows. In section 2 we discuss regional trends in GDP growth and overseas capital flows. In section 3 we provide a simple theoretical model and use it to discuss the empirical growth literature for each source of foreign capital. Of particular importance is a detailed look at the literature on remittances and evidence as to why they should be viewed as a vehicle for investment. In section 4 we discuss our empirical specification and how it overcomes the endogeneity issues common in the literature. In section 5 we review the data used. In section 6 we discuss our results and in section 7 we conclude.

\section{Data Trends}

The data on GDP growth, overseas development assistance and migrant remittances are taken from the World Bank's World Development Indicators (WDI). The data on FDI inflows are taken from UNCTAD.

\section{Figure 1 here}

Figure 1 shows the GDP per capita growth rate between 1984 and 2008 for a number of developing regions. Clearly GDP per capita growth has been positive for each region over much of the sample. Yet all regions, excluding East Asia \& Pacific, have experienced negative growth rates at some point. This is particularly true for SubSaharan Africa which has experienced negative growth for at least 11 years across the sample. In contrast, the growth rates in Asia have been consistently higher, in some cases over 10 per cent (even accounting for the financial crisis in 1997). 
GDP clearly has a cyclical pattern reflecting the swings of the business cycle. Despite this, the pattern of migrant remittances, overseas development assistance and foreign direct investment is quite different. Figure 2 shows workers remittances to the developing regions. From a fairly low base in 1984, with each region’s series broadly in line with one another, there appears to be an explosion around the mid 1990's. This is most notable for Asia and Latin America \& Caribbean. What is particularly striking is a comparison of the data on migrant remittances with the data on official development assistance (Figure 3). As can be seen, for many of the regions, workers remittances are far higher than overseas aid. Considering there has been a vast and controversial literature on the impact of aid on growth, it is perhaps surprising that there have been so few studies that have looked at the growth impacts of migrant remittances.

\section{Figure 2 here}

Figure 3 plots trends in overseas development assistance (ODA). Aid appears to be quite volatile in comparison to remittance flows. ODA falls considerably by approximately \$5 billion in SSA between 1994 and 2000 but since then it has increased by about $\$ 40$ billion. This reflects the political economy of aid donorship of developed countries in recent years.

\section{Figure 3 here}

Figure 4 shows inward FDI flows. The data reveals that FDI is significantly larger than the other two sources of foreign capital. Unsurprisingly, the data also shows the vast amount of FDI being done in China and South East Asia. Interestingly, since 2004 there has also been a significant pickup in FDI to Africa.

Figure 4 here 


\section{Theoretical Model and Literature Review}

The underlying theory we use is motivated by a standard growth model where foreign direct investment (FDI), overseas development assistance (ODA), and migrant remittances are all introduced as components of investment (see Burnside and Dollar (2000), Catrinescu et al. (2009)). Each financial flow finances the investment that determines economic growth. Investment in itself is the aggregate of public and private investment such that public investment is partly financed by aid, whilst private investment is composed of gross capital formation, foreign direct investment and migrant remittances. We can write the production function as equation (1):

$$
Y_{t}=T_{t}\left(G_{t}+\phi A_{t}+D I_{t}+F D I_{t}+\lambda R_{t}\right)^{\theta}
$$

where $G_{t}$ is government investment spending, $A_{t}$ is Overseas Development Assistance (ODA), $\phi$ is the share of ODA used for public investment purposes, $D I_{t}$ is domestic investment, $F D I_{t}$ is foreign direct investment, $R_{t}$ is remittances and $\lambda$ is the share of remittances devoted to private investment ${ }^{\mathrm{i}}$. Aid can influence growth directly or via public investment, whilst FDI and remittances generate growth via external private sources. The impact of institutions is modelled via the TFP term.

Hypotheses: the importance of capital transfers and institutions for growth. In recent years the role of institutions and the impact they have had on development has received considerable attention. As Rodrik (2000) points out, development policy during the 1980's had an excessive focus on price reform, i.e. privatisation and liberalisation. By the 1990's this over reliance became apparent and created divisions 
between the neo-classical economics of the Washington institutions (the IMF and the World Bank) and the developing countries they were trying to serve. It has become clear that institutions act as the bedrock of a successfully functioning mixed economy in that the market is seen as being embedded in these institutions.

Key papers by La Porta (1997) and Acemoglu (2001) have begun to look in more detail in terms of the classification of different types of institution. La Porta (1997) stresses the importance of property rights whilst Acemoglu (2001) focuses on colonial origins in other words initial conditions in terms of institutional quality and institutional development. As Rodrik (2004) points out there is now widespread agreement among economists that institutional quality holds the key to prevailing patterns of prosperity around the world.

The essential thrust of this paper is not merely to highlight the importance of FDI, ODA and remittances for growth, or to examine the importance of institutions, but to explore the relationships between these variables. As we discuss below, the existing literature examines these partial relationships, to varying degrees, with a larger literature focussing on FDI, a sizeable literature on ODA, and a much smaller literature on remittances. What is most interesting however, and perhaps surprising, is that much of the cross country literature that focuses on institutions, does so by seeking to determine a direct relationship between institutional quality and development or growth. We seek to extend this literature, by examining the importance of a range of institutional features across a range of countries, in order to determine whether there are interaction effects with the three forms of capital flow. 


\subsection{Foreign Direct Investment}

Theoretically there are a number of ways in which FDI can cause economic growth. As a starting point the standard Solow-type neoclassical model suggests that FDI increases economic growth by adding to the capital stock. Further, most micro-based analysis of the impact of foreign investment, see for example Aitken and Harrison (1999), or Haddad and Harrison (1993), suggest that foreign owned production is more productive than domestically owned production, and this assumption has formed the basis of a theoretical literature, based on the models of Grossman and Helpman (1991) and Rivera-Batiz and Romer (1991). Drawing on the work of Romer (1990) and Aghion and Howitt (1992), this approach seeks to link FDI flows to the wider literature that embeds endogenous technological change theories into general equilibrium models to analyse the relationship between international trade, technological change and growth.

For instance, Rivera-Batiz and Romer (1991) outline two channels for the transfer of technological knowledge: (i) the transmission of ideas which can be traded independently of goods, and (ii) trade in intermediate and capital goods that embody technology. It is argued that FDI has an impact on both of these channels, thus generating endogenous growth; see for example Borenzstein et al (1999) or Balasubramanyam et al (1996).

Although the impact of FDI on growth seems to have attained the status of what Herzer et al. (2007) have called a "stylised fact", a more careful reading of the literature may be required. For example, it might be the case that FDI just crowds out domestic investment. In addition, as Agosin and Machado (2005) argue, different types of FDI, for example mergers and acquisitions, may have no impact on the capital stock. It may 
just transfer resources from domestic to foreign residents with no resulting impact on domestic productivity via spillovers. Indeed, as Gorg and Greenaway (2004) have shown in their survey of the literature, only 6 out of 25 studies have found a positive relationship between spillovers from foreign owned firms to domestic owned firms.

It is interesting to note that while much of this literature highlights the potential endogeneity problem (that countries with greater potential for growth are more likely to attract FDI), it is also fair to say that, due to data limitations, attempts to address this have been rather limited. This, along with a discussion of the importance of institutions at a rather superficial level is one reason why the literature is so contradictory. We seek therefore to address both of these issues. As we discuss above, we examine the importance of institutions in the context of the extent to which they contribute to growth when combined with inward capital flows, but also the extent to which institutions attract those flows. Azman-Saini et al (2010) for example discuss this in the context of financial liberalization, but not in terms of institutions more generally.

\subsubsection{Interactions between institutions and FDI}

Previous research on the importance of institutions suggests a causal relationship between institutional reform and economic performance (Babeckỳ and Campos 2011). The perceived mechanisms on which this largely macro literature is based, relate institutional reform to development. Reforms reduce investment risk, generating greater returns to private sector investment and innovation, and eliminating sources of corruption (Ades and Di Tella 1999; Dreher et al. 2007; Boerner and Hainz 2009). Based on this, developing and transition countries are urged by multilateral agencies to improve their institutions and national governance structures. The expectation is that 
domestic industries will benefit in the long run, though many of the potential mechanisms remain under explored.

Links between institutional quality and private sector development have been examined in a number of papers, for example, recent work in transition countries, Coricelli et al (2012) highlights the importance of institutional quality for private sector development. This is explained in terms of capital market efficiency, either in terms of property rights encouraging investment, or in freedom from corruption reducing risk and transactions costs and therefore encouraging FDI.

We therefore explore the relationships by which the various forms of transfer foster economic growth, and the importance of institutions in this process.

In simple terms, where host country institutions fail to protect intellectual property rights, or the rights of minority investors, then this will impact on the extent to which FDI will stimulate growth. This occurs not merely through a reduction in the propensity of firms to invest in the country, but will also impact on technology transfer, and the extent to which inward investors engage with the host country firms. This phenomenon is widely discussed in the spillovers literature, in the context of firm level linkages (Smarzynska-Javorcik 2004), but the importance of institutions in this context is not discussed.

Hypothesis 1: While FDI generates growth, the interaction between property rights protection and FDI is important in determining the extent to which FDI generates growth. 


\subsection{Official Development Assistance}

Official Development Assistance (ODA) and the reform conditions surrounding it underpin the international community's development strategy. As pronounced on many occasions, and argued for by notable economists and celebrities, many countries are committed to achieving the policy goal of contributing $0.7 \%$ of GNP as ODA. The moral argument in favour of foreign aid, as summarised by Riddell (2007), is based on a number of factors. These include arguments based on solidarity or what could be called a humanitarian imperative. They also stem as a response to the extreme poverty and inequality faced by individuals in the developing world. Many proponents of foreign aid take the view that ODA can enhance human freedom (Sen 1999) and help to secure a safer and more peaceful world. This suggests that the performance of foreign aid can be assessed via a number of different metrics. We choose economic growth, the most common metric used by economists.

The literature that examines the impact of foreign aid on economic growth has generated much controversy. There have been a number of papers that have found statistical evidence either way. This empirical discrepancy feeds through into the popular media, with commentators from different poles of the political spectrum sensationalising the debate. It is often felt that opponents of aid take the view that it is a form of wealth distribution, whereby poor people in rich countries send money directly to rich people in poor countries (Bauer 1972). Whereas proponents of ODA make the case on altruistic grounds (Stern 1974), they have a more optimistic view of the impact of foreign aid. 
The benchmark study in this field, described by Easterly et al. (2004) as seminal, is by Burnside and Dollar (2000). They find that on its own aid has no effect on growth, although when it is interacted with a "sound" monetary and fiscal policy environment there is a conditional effect. Other papers have found similar results using other conditioning variables: e.g. Burnside and Dollar (2004) interact aid with the level of law and order; Chauvet and Guillaumont (2004) look at the impact of political stability; Guillaumont and Chauvet (2001) look at external shocks; and Svenson (1999) controls for the effects of democracy. Nevertheless, other studies reject these findings. Easterly et al. (2004) re-estimate Burnside and Dollar (2000) with new data and find far less evidence that aid has a positive impact on growth even when accounting for institutions. In addition, Alesina and Weder (2002) find that more corrupt countries do not receive less aid. This result is attenuated by Brautigam and Knack (2004) who show that high levels of aid in Africa are associated with deterioration in governance.

Another problem the literature has tried to address is the issue of endogeneity. This is endemic in much cross-country growth research. In terms of the aid-growth debate, it might be that aid just increases when there is a natural or humanitarian disaster; or, it may increase in countries that are economically successful. To address this issue, the common approach in the literature is to use instrumental variables estimation, but if these instruments are weak (or invalid) the results become highly questionable.

\subsubsection{Interactions between ODA and institutions}

To control for institutions in cross-country growth research it is common to interact institutional variables with the core regressor of interest. For example, in terms of the aid literature, Burnside and Dollar (1997) use the effectiveness of monetary and fiscal 
policy, though of course policy effectiveness is in itself both an arbitrary measure, and dependent on the nature of institutional quality. Here we postulate that the effectiveness of aid is dependent on the quality of the bureaucracy to interact with aid agencies in the deployment of all sorts of development assistance. As Easterly (2012) points out: "Bureaucracy works best where there is high feedback from beneficiaries, high incentives for the bureaucracy to respond to such feedback, easily observable outcomes, high probability that bureaucratic effort will translate into favourable outcomes, and competitive pressure from other bureaucracies and agencies. In short, bureaucracy works best when it functions something like a free market.”

The measure of bureaucratic quality we use accounts for the institutional strength and quality of the bureaucracy, higher country scores are generated where the bureaucracy has the strength and expertise to govern without drastic changes in policy, is autonomous from political pressure and has an established mechanism for recruitment and training. In a sense, all core features of a free market that Easterly (2012) argues are important for effective aid disbursement.

Hypothesis 2: While ODA generates growth, the interaction between ODA and bureaucratic quality, in terms of the ability of a country to effectively manage and distribute the beneficial effects of ODA, effects the extent to which ODA generates growth.

\subsection{Remittances}

The literature concerned with the relationship between migrant remittances and economic growth is in its infancy and is no less controversial than the literatures 
discussed above. Much of this controversy appears to centre on a debate as to whether remittances are in fact a form of capital transfer or simply income. Canales (2002) argues that remittances are used as recurrent household expenditure. He concludes that the possibility of using remittances for any sort of productivity enhancing activity is severely constrained by the economic hardship most remittance-receiving households' face. However, Woodruff \& Zenteno (2001) and more recently Giuliano and RuizArranz (2009) show that remittances do indeed act as a tool of development via investment. As far as we know Giuliano and Ruiz-Arranz (2009) are the first to estimate an investment equation that includes migrant remittances. They state that it is "remarkable" that the coefficient estimate corresponding to the remittance variable is positive and significant across all specifications. In addition to this, other studies, (see Taylor 1992 and Adams and Cuecuecha 2010) have found other links, with the latter finding it through education.

Because of this divergence in opinion it is perhaps not surprising that the literature which focuses on the relationship between migrant remittances and economic growth has typically provided a set of mixed results. Chami et al. (2003) find that remittances have a negative impact on economic growth. They build a simple theoretical model that motivates remittances through altruism at the family level. This methodology can be contrasted with what they call the "portfolio" approach whereby remittances can be viewed in a manner similar to the other sources of foreign capital flows. Their empirical analysis provides evidence that remittances are counter-cyclical; suggesting that remittances increase when economies are on a downward path. However, the methodology they use does not fully account for endogeneity. They use the US income gap and interest rate gap as instrumental variables for remittances and run a simple 
2SLS model. Lucas (2005) is critical of this choice; he argues that the insignificance of the interest rate gap in the first stage regression does not seem to eliminate the endogeneity bias. To address the endogeneity issue, Barajas and Chami et al. (2009), in a follow-up paper, introduce a novel instrument that they believe represents a significant improvement both over internal, lag-driven instruments (see discussion below) as well as other previous attempts at obtaining an external instrument. Again they find no significant positive relationship between remittances and growth; indeed they often find a negative relationship. They conclude that remittances are a form of social insurance to help family members finance life's necessities and that remittances don’t typically turn their recipients into entrepreneurs.

In contrast, Giuliano and Ruiz-Arranz (2009) use a different empirical strategy and find support for the "portfolio" approach. They see remittances as a mechanism to ease credit constraints. They use Systems GMM, following the methodologies of Anderson and Hsiao (1981), Arellano and Bond (1991) and Blundell and Bond (1998), to control for endogeneity and find that remittances have a positive impact on economic growth in countries that have a lower level of financial sector development. This suggests that there is a threshold which countries have to pass through which eventually renders the effects of remittances minimal. They use a dummy variable to show this and also provide two robustness checks by splitting the sample and by using threshold estimation. In addition, Pradhan et al. (2008) use random effects and fixed effects estimators and again find that remittances have a positive impact on economic growth across a sample of 39 developing countries. 


\subsubsection{Interactions between remittances and institutions}

One limitation of the Giuliano and Ruiz-Arranz (2009), as they point out, is that the study does not fully take into account other possible country characteristics, including institutional aspects. Catrinescu et al. (2009) seek to address this by using a dynamic panel GMM specification, employing data from the Inter Country Risk Guide (ICRG). They use a range of specifications and although the results are somewhat inconclusive, they certainly do not find a negative relationship. Indeed, once they interact remittances with institutions they observe a positive and significant effect of remittances on growth. There results suggest that the most important institutional variables are law and order, government stability and socioeconomic conditions. Rather surprisingly it seems that the investment profile measure (which essentially measures contract viability/expropriation, profits repatriation and payment delays) is insignificant across all of their specifications.

Taken together, this literature stresses several considerations in terms of the potential importance of remittances. Firstly, that remittances become relatively more important in the poorest countries of the world, and secondly the extent to which they become more important in the direst of circumstances, as institutions break down for example. We hypothesise therefore, that not only do remittances matter in poor countries, but that a minimum level of institutional protection is required to facilitate this. If for example a huge proportion of remittances are swallowed up in transactions costs, the informal economy and outright theft, then the effect of remittances will be significantly reduced. In order to capture this, we interact remittances with the most fundamental measure of institutional quality, which is the protection afforded to people through law and order. 
Hypothesis 3: While migrant remittances generate growth, the interaction between law and order and migrant remittances determines the extent to which remittances generates growth.

\section{Estimation and Econometric Considerations.}

A common problem in cross-county growth research (Temple 1999) is the endogeneity between growth and the sources of growth, in this case the flows of capital into a country. Numerous authors have commented on this within the single equation framework, though have been unable to more than partially solve this through the use of instruments as lags. Our methodology uses a 3-Stage Least Squares panel systems estimator that treats economic growth, foreign direct investment, overseas development assistance and migrant remittances as endogenous. The essential advantage of this approach is that, providing the stochastic terms in the variance-covariance are independent of one another, then this method is more efficient than single equation approaches.

Attempts to find a suitable instrument for FDI in the GDP equation in the literature has been less than convincing, and has typically relied on variables that also enter the GDP equation (see Vu and Noy (2009) or Chowdhury, and Mavrotas (2006)). In practice however, this places two demands on the model. Firstly, that there is no specification error, or omitted variable bias in the equations, as by construction this will generate bias in the other equations, and secondly that the residuals are independent of one another, both in cross sectional terms and across time. Kmenta (1997) and Greene (1993) demonstrate how the standard Hausman (1978) can be applied to this problem. We analyse the impact of each of the endogenous variables on each other and examine 
a number of other control variables common to the literature on growth (see Stehrer and Woerz (2009) for a similar approach). We extend this however in a number of ways. Firstly, we consider not merely the relationship between FDI and growth, but the mitigating factors in this relationship, as well as other sources of external capital. This links to the discussion above concerning for example the interactions between bureaucracy and aid, or between remittances and law and order, as well as the contributions to growth that these sources of capital make more generally.

Instead of controlling for potential endogeneity with instrumental variables estimation our preferred strategy is to jointly estimate equations 2-5 below, allowing for simultaneity between GDP growth, foreign direct investment, overseas development assistance and workers remittances.

$$
\begin{aligned}
& G D P_{i t}=\beta_{0}+\beta_{1} I_{i}+\beta_{2} F D I_{i t}+\beta_{3} O D A_{i t}+\beta_{4} R E M_{i t}+\beta_{5} I P_{i t}+\beta_{6} L O_{i t}+\beta_{7} B Q_{i t}+\boldsymbol{\beta} \mathbf{X}_{i t}+u_{i t} \\
& F D I_{i t}=\alpha_{0}+\alpha_{1} I n_{i}+\alpha_{2} O D A_{i t}+\alpha_{3} R E M_{i t}+\alpha_{4} G D P_{i t}+\boldsymbol{\alpha} \mathbf{Z}_{i t}+\zeta_{i t} \\
& O D A_{i t}=\gamma_{0}+\gamma_{1} I n_{i}+\gamma_{2} F D I_{i t}+\gamma_{3} R E M_{i t}+\gamma_{4} G D P_{i t}+\gamma \mathbf{Z}_{i t}+\psi_{i t} \\
& R E M_{i t}=\phi_{0}+\phi_{1} I n_{i}+\phi_{2} F D I_{i t}+\phi_{3} O D A_{i t}+\phi_{4} G D P_{i t}+\varphi \mathbf{Z}_{i t}+\theta_{i t}
\end{aligned}
$$

Where $G D P_{i t}$ is per capita GDP growth; $F D I_{i t}$ is foreign direct investment as a percentage of GDP; $O D A_{i t}$ is official development assistance as a percentage of GDP; and $R E M_{i t}$ is migrant remittances as a percentage of GDP. In the dynamic specifications we include the lagged dependent variable, to allow for convergence; $I P_{i t}$ is investor profile (captures the quality of the investment environment); $L O_{i t}$ is law and order (captures the quality of the judicial system); $B Q_{i t}$ is bureaucratic quality; and the vector $\mathbf{X}_{\mathbf{i t}}$ contains a number of additional control variables: (1) Gross Capital 
Formation, which in this context is taken to be net of other forms of investment, in this case the three international transfer variables, FDI, ODA and Remittances; (2) trade as a percentage of GDP; (3) human capital; (4) population growth; (5) inflation; (6) landlocked dummy; (7) regional dummies for Asia, Latin America and Sub-Saharan Africa (8) an interaction between remittances and the HDI index ${ }^{\text {ii. }}$ and (9) the interaction terms between our institutional ICRG variables and the endogenous variables. The interactions used are the following:

$$
\begin{aligned}
& I P_{i t} \times F D I_{i t} \\
& L O_{i t} \times R E M_{i t} \\
& B Q_{i t} \times O D A_{i t} .
\end{aligned}
$$

The coefficients estimated for each of these interaction terms tells us whether institutions enhance the effects of the endogenous variables on growth. We only include them in the growth equation, the results of which are in our 2nd specification below. Finally, the vector $\mathbf{Z}_{\mathbf{i t}}$ is a subset of $\mathbf{X}_{\mathbf{i t}}$ as we do not include all of the control variables in each equation.

While the use of panel data to estimate systems of simultaneous equations is well understood, this generally involves converting the data to differences and estimating the system by either three stage least squares (3SLS) or generalised methods of moments (GMM) using lagged values as instruments to generate orthogonality conditions on differenced data. This is a straightforward simultaneous equations estimator following Holtz-Eakin et al. (1988) or Cornwell et al. (1992), which allows for individual effects both within individual equations and in the covariance matrix between the equations, 
based on the more general approach of Arrellano and Bond (1991) or the more recent Blundell and Bond (1998) GMM systems estimator. These approaches rely on employing lagged values as instruments; so with short panels of unbalanced data such estimation reduces the number of observations dramatically.

However, an additional problem that we face is that the data contains some timeinvariant variables (for example the location variable, the landlocked dummy and the ICRG data which varies marginally over time). As such, one cannot adopt one of these approaches, as differencing the data becomes infeasible. We therefore adopt the 3SLS “within” estimation with error components suggested by Baltagi and Li (1992), based on Baltagi (1981). In practice this involves estimating equations (2 to 5) separately using a standard "within estimator" iii method, and then calculating the covariance matrix between the equations using the errors. The data are then transformed by dividing through by the square root of the covariance, and finally equations (2 to 5) are estimated by 3SLS employing the transformed data. ${ }^{\text {iv }}$ As the use of 3SLS over 2SLS implies further restrictions in the model, these restrictions can be tested again using a standard Hausman F-test, and in all cases these restrictions are not rejected ${ }^{\mathrm{v}}$.

We run a number of specifications using annual data and using data averaged over 5 yearly periods ${ }^{\mathrm{vi}}$. The annual approach is uncommon in the literature because the data for GDP Growth is noisy (see Figure 1). As Harrsion (1996) points out, one of the problems in using annual data to identify the determinants of long-run growth is that short-run or cyclical fluctuations could affect the observed relationship between policy variables and growth. Nevertheless, we find that the performance of the two 
specifications offer similar results. This gives further weight to the use of the 3SLS systems methodology

\section{Data}

The core data used in this study is taken from the World Bank’s World Development Indicators (see Table A1 for descriptive statistics and Table A2 for correlation coefficients). Our dependent variable is GDP per capita growth. The other endogenous variables ODA, FDI and workers remittances ${ }^{\text {vii }}$ are expressed as a percentage of GDP. Other variables taken from the WDI are trade as a percentage of GDP, population growth and inflation. The FDI data is from UNCTAD, the human capital data is taken form Barro and Lee (2000) and the data on institutions is taken from the Inter Country Risk Guide (ICRG). We use three of the ICRG measures: (1) Bureaucratic Quality (maximum score of 4) measures the bureaucracy's ability to adapt to changes in policy or interruption in government services. Countries that have an independent bureaucracy, autonomous of political interference, for example in recruitment, obtain a higher rating; (2) Law and Order (maximum score of 6) is a measure based on two subcomponents. One of which is the strength and impartiality of the judicial system, the other is an assessment of the observance of the law; and (3) Investment Profile (maximum score of 12) is an assessment of the factors that affect the risk of an investment. This measure is split up in to three sub-components - contract viability, profit repatriation and payment delays.

We construct an unbalanced panel of annual observations from 1984 to $2007^{\text {viii }}$ and an unbalanced panel that contains 5 year averages. Our data contains almost the entire sample of developing countries from the WDI. 


\section{Results}

Table 1 reports the results for the baseline specification of our 3SLS estimation on annual data ${ }^{\text {ix }}$. These results exclude the interaction terms. Our main focus for this specification is the growth equation. As can be seen, FDI and remittances both have a positive and significant impact on GDP growth. This is consistent with previous studies by Hansen and Rand (2006) and Catrinescu (2009). In contrast, overseas development assistance appears to have a negative and significant impact on GDP growth, following Easterly et al. (2004). When we interact remittances with the HDI dummy (which equals 1 for countries with 'medium human development' and 0 for countries with 'low human development') there is no significant impact. This suggests that remittances are just as important to countries with a low HDI score compared with countries with a ‘medium’ HDI score. This somewhat contradicts Giuliano and Ruiz-Arranz (2009) observation that remittances have a greater impact in countries with a lower level of financial sector development. Additionally, we also observe a positive and significant parameter estimate for the lagged rate of growth, suggesting growth divergence amongst the countries in our panel. In general the lagged dependent variables behave as expected, with FDI and remittances showing a degree of divergence, and ODA showing some (marginally significant) convergence.

\section{Table 1 here}

The parameter estimates for two of the institutional variables law \& order and bureaucratic quality are positive and significant signifying that the maintenance of an impartial judicial system and a general abeyance of the law in conjunction with a productive bureaucracy are good for growth. In contrast, the parameter estimate for the protection of property rights is negative but insignificant. This suggests that property 
rights protection may be less important compared to the other two factors for developing country growth.

In addition, the estimated coefficient for human capital is positive which supports Mankiw, Romer and Weil (1992); the coefficient estimate for trade as a percentage of GDP is positive, providing evidence similar to Sachs and Warner (1995); the coefficient estimate associated with inflation is negative, suggesting that macroeconomic instability is bad for growth (see Barro 1991); and finally, the coefficient estimate for population growth is negative, consistent with Solow (1956).

\section{Table 2 here}

Having established the baseline model, and the importance of both institutions and capital flows for development, our attention then turns to the tests of our specific hypotheses, which relate to the interaction terms. Table 2 reports the results for the 3SLS estimation with institutional interaction terms as the endogenous variables in the growth equation. The results show unqualified support for our hypotheses, in that, when we interact each of the capital transfer variables with the ICRG variables all sources of foreign capital generates growth. FDI interacted with investor protection contributes significantly. This may be interpreted as countries with higher levels of investor protection attract "better" FDI. This may be in the form of newer technology, with better IPR protection encouraging international technology transfer. Equally, countries with better investor protection attract larger scale FDI, where firms are willing to take bigger ownership stakes. This again encourages more technology transfer. Similar results are found for the ODA and remittances interactions. As suggested above, 
remittances are more effective in stimulating growth where those remittances are protected by law and order, and aid is much more effective in countries with an effective bureaucracy.

In addition to these results, conditional divergence is again observed with the coefficient associated with the lagged dependent variable positive and significant. The estimates for the other variables are again as expected: trade as a percentage of GDP $(+)$, human capital (+), inflation (-) and the landlocked dummy (-).

As well as the results for the baseline specification, it is also important to analyse the other equations in the system. We do this here because this is our preferred specification and we observe some important results.

The first result to consider is the coefficient estimate for ODA as a percentage of GDP in the FDI equation. The estimate is negative suggesting that in countries where there are significant levels of aid, FDI is limited. This is consistent with the positive coefficients in the FDI equation for investor profile and law \& order. It suggests that firms are unlikely to do FDI in regions with low levels of development.

The next interesting result can be seen for the coefficient estimate in the ODA equation for remittances as a percentage of GDP. The estimate is large in magnitude and significant suggesting that remittances and aid go hand in hand. This can also be observed in the remittance equation in terms of the ODA coefficient. 
Another coefficient estimate that is of significance is the landlocked dummy variable. It would appear that being landlocked has no discernible negative impact on the ability to do FDI or on the amount of official development assistance. In contrast, the coefficient for the landlocked dummy in the remittance equation is negative. Presumably we observe this pattern because it is far harder to migrate away from landlocked countries in order to send remittances.

Finally, and perhaps the most significant additional result from our analysis concerns the effectiveness of aid targeting. As can be seen in the growth equation, ODA only appears to have a positive impact on growth conditional on the quality of the bureaucracy to disseminate it. However, if we look at the coefficient for bureaucratic quality in the ODA equation it comes out as negative and significant. This suggests ODA is directed to countries with a poor bureaucratic quality - adding weight to the idea that aid is poorly targeted (see Brautigam and Knack (2004)).

\section{Robustness}

As a robustness check we also do the analysis using data averaged over 5-year periods. The results for the 3SLS Systems Estimator are provided in Table 3 for the model which includes institutional interaction terms with our endogenous variables. The results are similar to the specifications that use annual observations. Once again FDI, ODA and remittances all have a positive impact on growth once institutions are taken into consideration. And again the coefficient for Bureaucratic Quality in the ODA equation is negative and significant - suggestive of poor aid targeting. These results provide good support for the use of our 3SLS systems approach in the future as it performs well using annual observations. It would appear that the 'noise' problem of 
annual GDP per-capita growth is not as severe as once thought when using this methodology.

\section{Table 3 here}

\section{Conclusion}

It is clear from our analysis that both foreign direct investment and migrant remittances have a positive impact on growth in developing countries. In addition, this is attenuated by a better institutional environment; in that countries that protect investors and maintain a high level of law and order will experience enhanced growth. In contrast, the relationship between aid and growth is not as clear cut. On its own aid appears to have a negative impact on growth and it appears to be poorly targeted. But when there is enough bureaucratic quality aid does begin to make a difference.

Interestingly, the magnitude of the coefficient estimates for FDI and remittances in the growth equation are very similar at 0.1246 and 0.1101 respectively. This suggests that remittances are nearly as important as FDI in terms of generating economic growth. This is a significant result considering the literature that looks at the impact of remittances on growth has been so limited.

The importance of institutions has received renewed consideration recently, not only with the recognition of Elinor Ostrom's Nobel Prize, but also the emphasis placed on these issues by President Obama. While the phrase "institutions matter" is a widely used one, it is surprising how little has been done in terms of seeking to quantify this, particularly in the context of the low growth rates of many of the poorest countries. We show here that improved institutional quality, not only attracts more inward investment, 
but also that this investment has a greater impact on growth. The policy lessons for this are clear.

These results give a good deal of credence to the "Washington consensus", in that in terms of growth rates institutions matter. This builds on the work by North (1973, 1981), La Porta (1997) and Acemoglu (2001). However, our results also illustrate why there has been so much controversy surrounding the importance of institutions in recent years. In themselves the institutional variables are not strongly linked to economic growth. However, they are strongly correlated with all three types of capital flow. Further, investor protection, bureaucratic quality and the maintenance of law and order increase the extent to which inward capital flows stimulate economic growth. This analysis therefore hints at evidence for Rodrik's (2004) theory that even if a country is below its potential steady-state level of growth, moderate movements in growth enhancing variables, in this case FDI and remittances may be the trigger that generates a sizeable growth payoff. 


\section{References}

Acemoglu, D., Johnson, S., Robinson, A. (2001) The colonial origins of comparative development: An empirical investigation. American Economic Review 91, 1369-1401.

Adams Jr, R.H., Cuecuecha, A., Remittances, household expenditure and investment in Guatemala. World Development (Article in Press).

Aghion, P., Howitt, P. (1992) A model of growth through creative destruction. Econometric Society 60(2), 323-51.

Agosin, M., Machado, R. (2005) Foreign investment in developing countries: does it crowd in domestic investment? Oxford Development Studies, 33 (2), 149-162

Aitken, B.J., Harrison A.E. (1999) Do domestic firms benefit from direct foreign investment? Evidence from Venezuela ? American Economic Review 89: 605-618.

Alesina, A., Weder, B. (2002) Do corrupt governments receive less foreign aid? American Economic Review 92 (4), 1126-1137.

Anderson, T.W., Hsiao, C. (1981) Estimation of dynamic models with error components. Journal of the American Statistical Association, 589-606.

Angelucci, M., Estrin, S. Konings, J. and Zolkiewski, Z. (2002) The Effect of Ownership and Competitive Pressure on Firm Performance in Transition Countries: 
Micro Evidence from Bulgaria, Romania and Poland. William Davidson Institute Working Papers Series 434, William Davidson Institute at the University of Michigan.

Antràs, P., Desai, M.A. and Foley, C.F. (2009) Multinational Firms, FDI Flows, and Imperfect Capital Markets. The Quarterly Journal of Economics, MIT Press, vol. 124(3), pages 1171-1219.

Arellano, M., Bond, S. (1991) Some tests for specification of panel data: Monte Carlo evidence and an application to employment equations. Review of Economic Studies 58, 277-297.

Azman-Saini, W. N. W., Law, S. H. and Halim, A. (2010) FDI and Economic Growth:New Evidence on the Role of Financial Market. Economics Letters 107, 211213.

Balasubramanyam, V.N., Salisu, M., Sapsford, D. (1996) Foreign direct investment and growth in EP and IS countries. The Economic Journal 106, 92-105.

Baltagi, B.H. (1981) Simultaneous equations with error components. Journal of Econometrics, 17, 189-200.

Baltagi, B.H., Li. (1992) A note on the estimation of simultaneous equations with error components. Econometric Theory, 8, 113-119.

Barajas, A., Chami, R., Fullenkamp, C., Gapen, G., Montiel, P. (2009) Do Workers’ Remittances Promote Economic Growth? IMF Working Paper 09/153. 
Barro, R.J. (1991) Economic growth in a cross section of countries. The Quarterly Journal of Economics, 106 (2), 407-443.

Barro, R.J., Lee, J. (2000) International Data on Educational Attainment. CID Working Paper No. 42.

Bauer, P. T. (1972) Dissent on development. Cambridge, Harvard University Press.

Blundell, R., Bond, S. (1998) Initial conditions and moment conditions in dynamic Panel Data Models. Journal of Econometrics 87 (1), 115-143.

Boerner, K., Hainz, C. (2009) The political economy of corruption and the role of economic opportunities. Economics of Transition 17 (2), 213-240.

Bond, S. (2000) GMM Estimation with persistent panel data: an application to production functions. Econometric Reviews 19 (3) 321-340.

Borensztein, E., De Gregorio, J., Lee, J.W. (1998) How does foreign direct investment affect economic growth? Journal of International Economics, 45,115-135.

Brautigam, D., Knack, S. (2004) Foreign aid, institutions, and governance in SubSaharan Africa. Economic Development and Cultural Change 52(2), 255-285.

Burnside, C., Dollar, D. (1997) Aid, policies, and growth. Policy Research Working Paper Series 1777, The World Bank. 
Burnside, C., Dollar, D. (2000b) Aid, policies, and growth. American Economic Review 90 (4), 847-68.

Burnside, C., Dollar, D. (2004) Aid, policies, and growth: reply. American Economic Review 94 (3), 781-784.

Canales, A. I. (2002) “El papel de las remesas en la capacidad de ahorro e inversión de los hogares en México.” In Jaciel Montoya (Ed.), Memorias del Encuentro Nacional: La Población en México, Cambio Demográfico y Consecuencias Sociales. Universidad Autónoma del Estado de México.

Carluccio, J., Fally, T. (2010) Foreign Entry and Spillovers with Technological Incompatibilities in the Supply Chain. CEPR Discussion Papers 7866, C.E.P.R. Discussion Papers.

Catrinescu, N., Leon-Ledesma, M., Piracha, M., Quillin, B. (2009) Remittances, institutions, and economic growth. World Development 37 (1), 81-92.

Chami, R., Fullenkamp, C., Jahjah, S. (2003) Are immigrant remittance flows a source of capital for development? IMF Working Papers 03/189 (Washington: International Monetary Fund). 
Chauvet, L., Guillaumont, P. (2004) Aid and growth revisited: Policy, economic vulnerability, and political instability. In: Tungodden, B., Stern, N., Kolstad, I. (Eds.), Toward pro-poor policies. Aid, institutions, and globalization. Washington and New York: World Bank and Oxford University Press 95-109.

Coricelli, F., Driffield, N.L., Roland, I and Pal, S. (2012) When does leverage hurtproductivity growth? A firm level analysis. Journal of international Money and Finance, vol. 31 (6) pp. 1674-1694

Cornwell, C., Schmidt, P., Wyhowski, D. (1992) Similtaneous equations and panel data. Journal of Econometrics 51, 151-181.

Chowdhury, A., Mavrotas, G. (2006) FDI and growth: What causes what? The World Economy 29 (1), 9-19.

Doucouliagos, H, Paldam, M. (2006) Aid effectiveness on accumulation: A meta study. Kyklos 59 (2), 227-254.

Dreher, A., Kotsogiannis, C., McCorriston, S. (2007) Corruption around the world: evidence from a structural model. Journal of Comparative Economics 35 (3), 443-466.

Easterly, W. (2012) The cartel of good intentions: the problem of bureaucracy in foreign aid. The Journal of Policy Reform 5:4, 223-250.

Easterly, W., Levine, R., Roodman, D. (2004) Aid, policies, and growth: comment. 
American Economic Review 94 (3), 774-780.

Giuliano, P., Ruiz-Arranz, M. (2009) Remittances, financial development and growth. Journal of Development Economics 90 (1), 144-15.

Görg, H., Greenaway, D. (2004) Much a do about nothing? Do domestic firms really benefit from foreign direct investment? World Bank Research Observer, Oxford University Press 19 (2), 171-197.

Greene, W. H. (1993) Econometric Analysis, Fifth Edition, Macmillan.

Grossman, G. M., Helpman, E. (1991) Trade, knowledge spillovers, and growth. European Economic Review 35, 517-526.

Guillaumont, P., Chauvet, L. (2001) Aid and performance: A reassessment. Journal of Development Studies 37, 66-92.

Haddad, M., Harrison, A. (1993) Are there positive spillovers from foreign investment? Evidence from panel data for Morocco. Journal of Development Economics 42, 51-74.

Hansen, H., Rand, J. (2006) On the causal links between FDI and growth in developing countries. The World Economy 29(1), 21-41.

Hansen, H., Tarp, F. (2001) Aid effectiveness disputed. Journal of Development Economics 64 (2), 547-70. 
Harrison, A. (1996) Openess and growth: A time-series, cross-country analysis for developing countries. Journal of Development Economics 48, 419-447.

Hausman, J. A., 1978. Specification Tests in Econometrics. Econometrica 46:12511271.

Herzer, D., Klasen, S., Nowak-Lehmann, F. (2007) In search of FDI-led growth in developing countries. Proceedings of the German Development Conference.

Holtz-Eakin, D., Newey, W., Rosen, H. S. (1988) Estimating vector autoregressions with panel Data. Econometrica 56 (6), 1371 - 1395.

Kmenta, J. (1997) Elements of Econometrics, Second Edition, University of Michigan Publishing.

La Porta, R., Lopez-de-Silanes, F., Shleifer, A., Vishny, R.W. (1997) Legal determinants of external finance. Journal of Finance 52, 1131-50.

Landes, D.S. (1998) The wealth and poverty of nations. WW Norton, New York.

Lim, E. (2001) Determinants of, and the relation between, foreign direct investment and growth: A summary of the recent literature. IMF Working Paper No. 01/175.

Lucas, R. E. B. (2005) International migration and economic development.Stockholm: Expert group on development issues. Swedish Ministry for Foreign Affairs. 
Mankiw, N.G., Romer, D., Weil, D.N. (1992) A contribution to the empirics of economic growth. The Quarterly Journal of Economics 107 (2), 407-437.

North, D., Thomas, R. (1973) The rise of the western world: A new economic history. Cambridge University Press.

North, D. (1981) Structure and change in economic history. Norton.

North, D. (1990) Institutions, institutional change and economic performance. Cambridge University Press.

Petersen, M.A. (2006) Estimating standard errors in finance panel data sets: Comparing approaches. Northwestern University.

Pradhan, G., M. Upadhyay, and K. Upadhyaya (2008) Remittances and Economic Growth in Developing Countries, European Journal of Development Research 20 (3), 497-506.

Riddel, R.C. (2007) Does foreign aid work. Oxford University Press.

Rivera-Batiz, L.A., Romer, P.M. (1991) International trade with endogenous technological change. European Economic Review 35 (4), 971-1001. 
Rodrik, D. (2000) Institutions for High-Quality Growth: What they are and how to acquire them. NBER Working Papers 7540, National Bureau of Economic Research, Inc.

Rodrik, D. (2004) Getting institutions right. Harvard University.

Romer, P.M. (1990) Endogenous technological change. Journal of Political Economy, 98 (5), 71-102.

Sachs, J.D., Warner, A. (1995) Economic reform and the process of global integration. Brookings Papers on Economic Activity. The Brookings Institution, 26(1995-1), 1-118.

Sen, A. (1999) Development as Freedom. Oxford University Press.

Solow, R. (1956) A contribution to the theory of economic growth. The Quarterly Journal of Economics 70 (1), 65-94

Smarzynska-Javorcik, B. (2004) Does foreign direct investment increase the productivity of domestic firms? In search of spillovers through backward linkages. The American Economic Review 94 (3), 605-627.

Stern, N.H. (1974) Professor Bauer on development. Journal of Development Economics 1, 191-211. 
Stehrer, R., Woerz, J. (2009) Attract FDI! - A Universal golden rule? Empirical evidence for OECD and selected non-OECD countries. The European Journal of Development Research 21(1), 95-111

Svensson, J. (1999) Aid, growth and democracy. Economics and Politics 11, 275-297.

Taylor, J. E. (1992) Remittances and inequality reconsidered: Direct, indirect, and intertemporal effects. Journal of Policy Modeling 14, 187-208.

Temple, J. (1999) The new growth evidence. Journal of Economic Literature 37(1), 112-156.

Vu, T.B., Noy, I. (2009) Sectoral analysis of foreign direct investment and growth in the developed countries. Journal of International Financial Markets, Institutions and Money 19 (2), 402-413.

Woodruff, C., Zenteno, R. (2001) Remittances and microenterprises in Mexico. UCSD Working Paper

Wooldridge, J. (2002) Econometric analysis of cross section and panel data. MIT Press. 
Figure 1: GDP per capita Growth

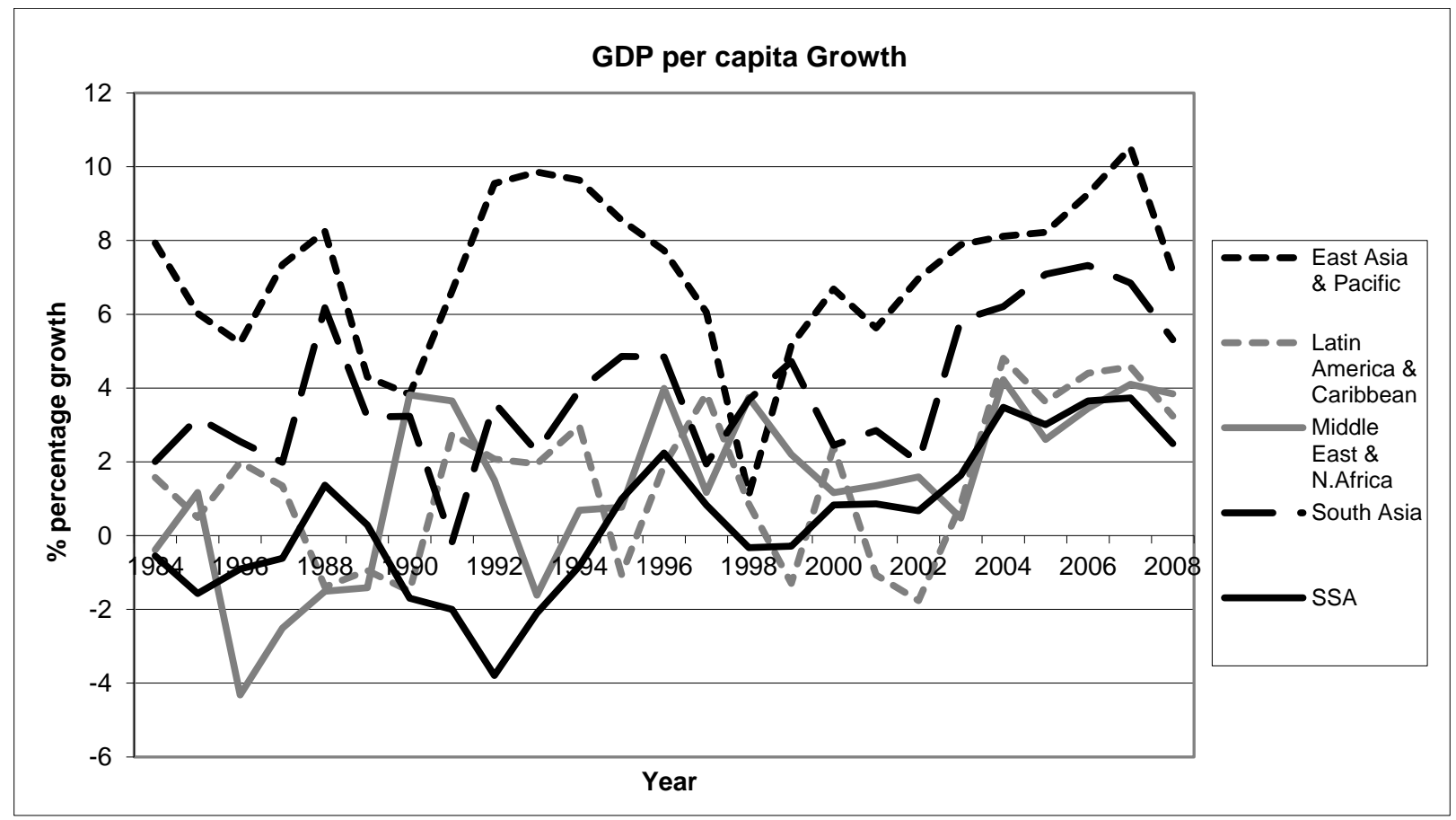


Figure 2: Workers Remittances

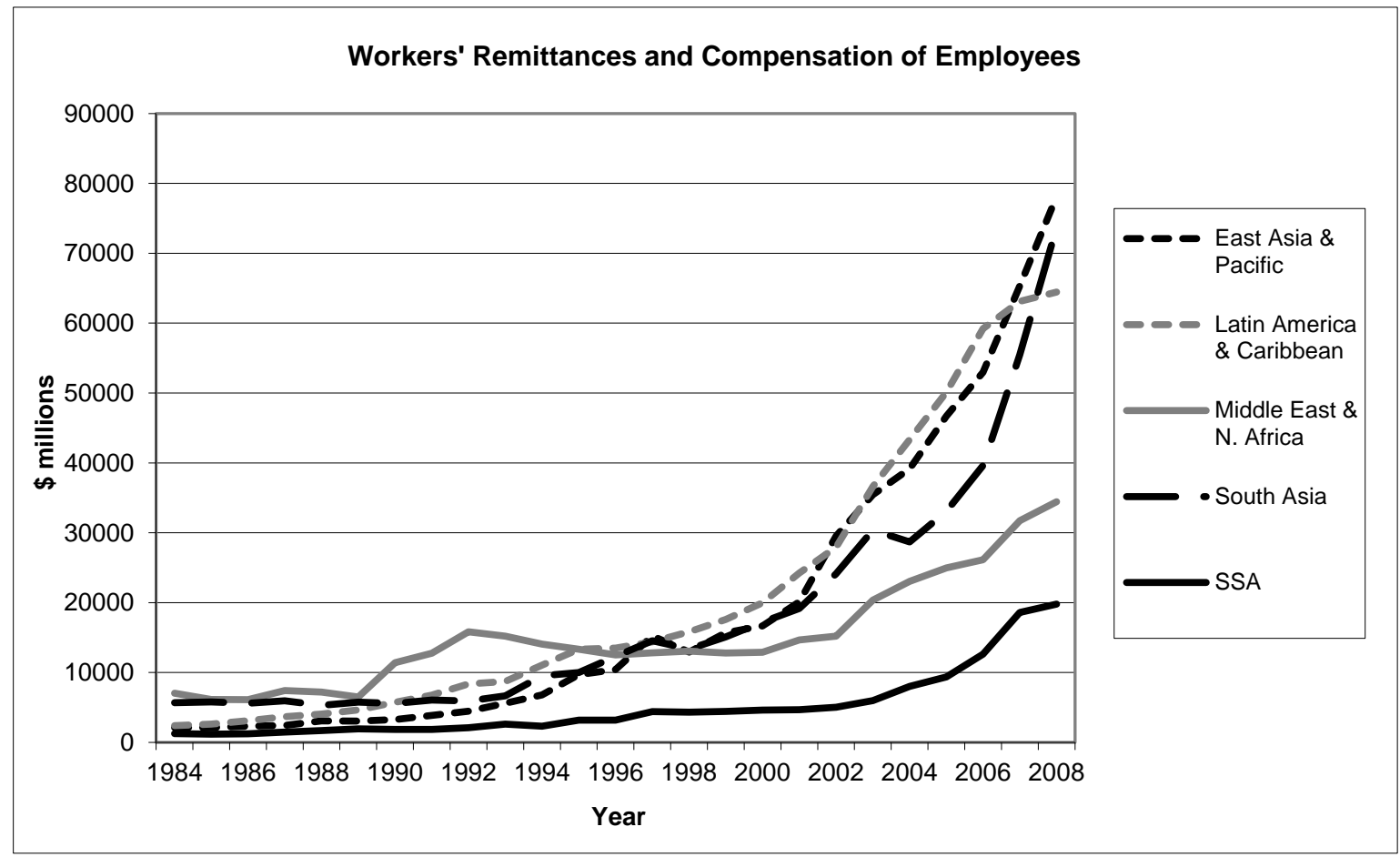


Figure 3: Official Development Assistance

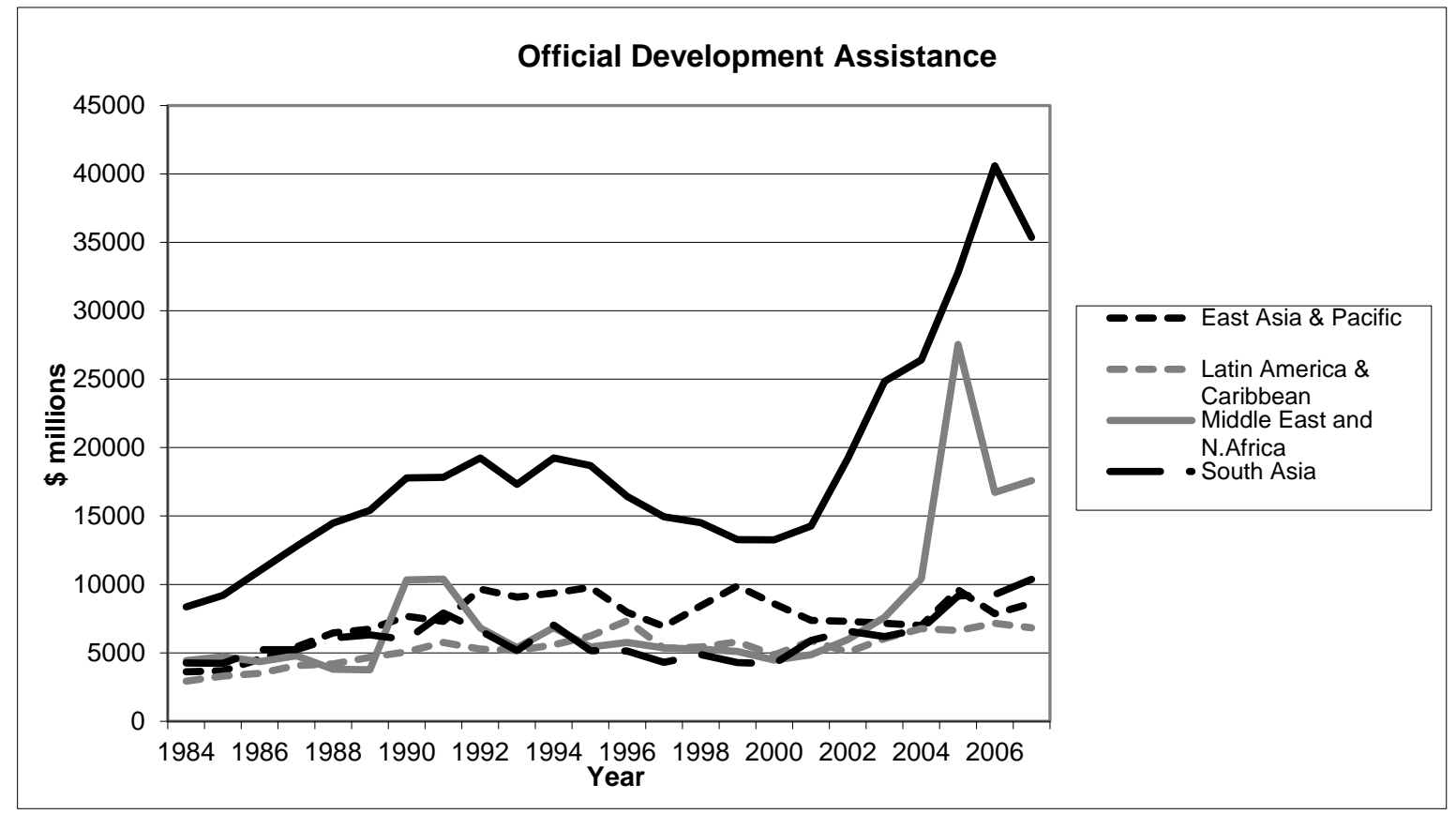


Figure 4: Inward FDI

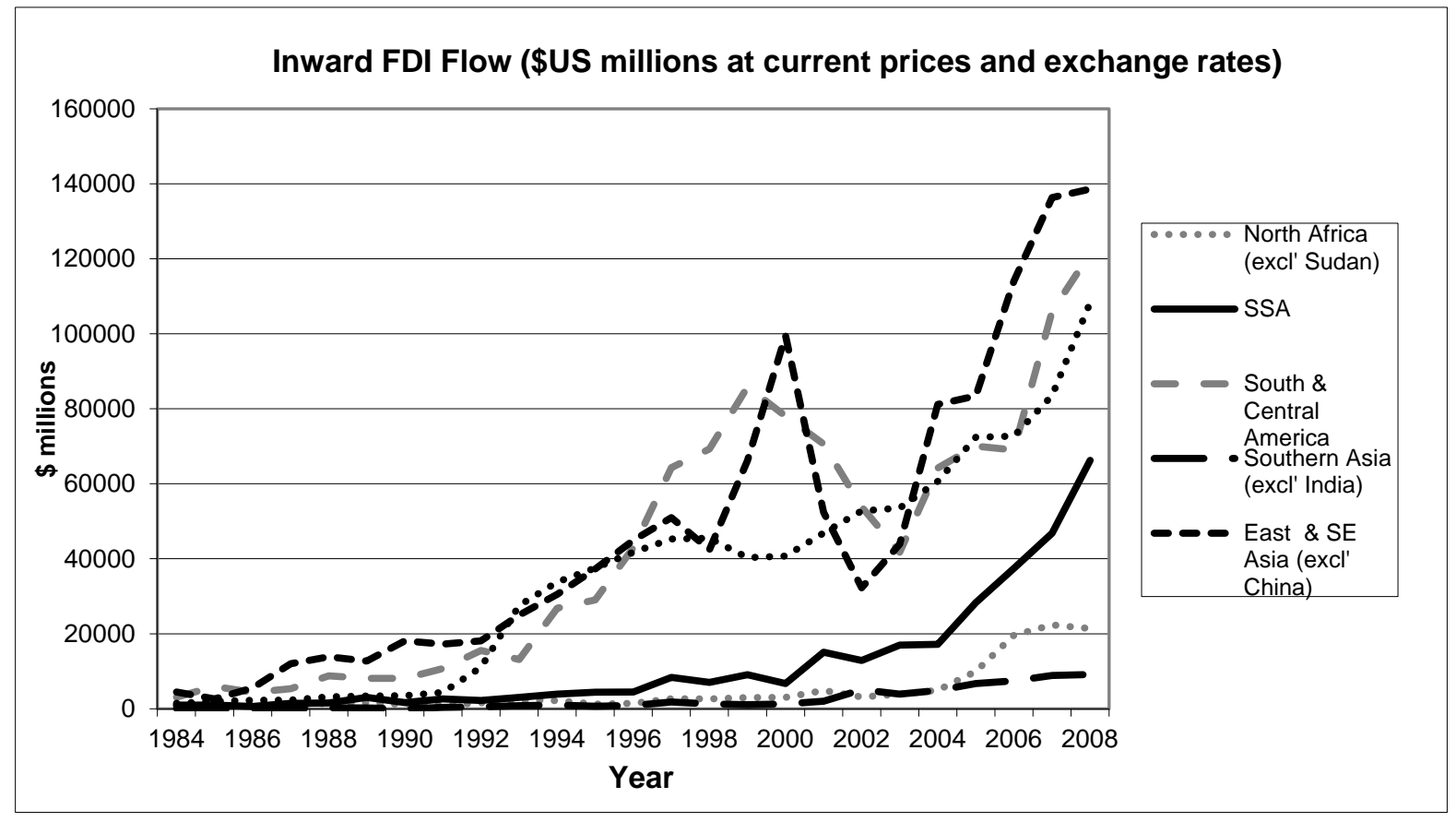


Table 1: 3SLS Results

\begin{tabular}{|c|c|c|c|c|}
\hline Model 1: 3SLS & $\begin{array}{l}\text { Growth } \\
\text { Equation }\end{array}$ & $\begin{array}{l}\text { FDI } \\
\text { Equation }\end{array}$ & $\begin{array}{l}\text { ODA } \\
\text { Equation }\end{array}$ & $\begin{array}{l}\text { Remittance } \\
\text { Equation }\end{array}$ \\
\hline Dependent Variable & GDPpc Growth & FDI \%GDP & ODA \%GDP & REM \%GDP \\
\hline \multirow[t]{2}{*}{ Lagged dependent variable } & $0.1960 * *$ & $0.3105^{* *}$ & -0.1360 & $0.5478^{* *}$ \\
\hline & 0.0239 & 0.1164 & 0.0831 & 0.1064 \\
\hline \multirow{2}{*}{ GCF } & $0.0736^{* *}$ & & & \\
\hline & 0.0243 & & & \\
\hline \multirow[t]{2}{*}{ GDP per capita Growth } & & -3.1973 & 3.3450 & -2.6677 \\
\hline & & 2.3676 & 1.7343 & 2.6515 \\
\hline \multirow[t]{2}{*}{ FDI \% GDP } & $0.0743^{* *}$ & & 0.4589 & -0.2743 \\
\hline & 0.0081 & & 0.0510 & 0.0817 \\
\hline \multirow[t]{2}{*}{ ODA \% GDP } & $-0.0514^{* *}$ & $0.6896 * *$ & & 1.0149 \\
\hline & 0.0120 & 0.0631 & & 0.0495 \\
\hline \multirow[t]{2}{*}{ REM \% GDP } & $0.0590 * *$ & $-0.3207 * *$ & $0.6417 * *$ & \\
\hline & 0.0153 & 0.0615 & 0.0316 & \\
\hline \multirow[t]{2}{*}{$\mathrm{REM} \times \mathrm{HDI}$} & 0.0083 & & & \\
\hline & 0.0139 & & & \\
\hline \multirow[t]{2}{*}{ Trade \% GDP } & 0.0313 & -0.0464 & & \\
\hline & 0.0258 & 0.1669 & & \\
\hline \multirow[t]{2}{*}{ Human Capital } & $0.1593 * *$ & $0.0488 * *$ & & \\
\hline & 0.0574 & 0.0021 & & \\
\hline \multirow[t]{2}{*}{ Population Growth } & -0.0091 & $-0.9394 * *$ & 0.9892 & -0.8270 \\
\hline & 0.0155 & 0.1083 & 0.0840 & 0.1134 \\
\hline \multirow[t]{2}{*}{ Inflation } & $-0.0011^{* *}$ & $-0.0012 * *$ & $0.0096 * *$ & $-0.0099 * *$ \\
\hline & 0.0000 & 0.00035 & 0.0003 & 0.0012 \\
\hline \multirow[t]{2}{*}{ Landlocked } & $0.0824^{* *}$ & $0.3894 *$ & -0.0828 & -0.0522 \\
\hline & 0.0351 & 0.2238 & 0.1876 & 0.2268 \\
\hline \multirow[t]{2}{*}{ ASIA } & $0.1265^{* *}$ & 0.4026 & 0.0467 & -0.1658 \\
\hline & 0.0437 & 0.2353 & 0.1556 & 0.2225 \\
\hline \multirow[t]{2}{*}{ LA \& CAR } & $0.1673^{* *}$ & $1.8198^{* *}$ & $-1.2913^{* *}$ & $1.0062 * *$ \\
\hline & 0.0471 & 0.2224 & 0.1946 & 0.2715 \\
\hline \multirow[t]{2}{*}{ SSA } & $0.2282 * *$ & -0.2150 & $0.9656^{* *}$ & $-1.7609 * *$ \\
\hline & 0.0466 & 0.3398 & 0.2176 & 0.2950 \\
\hline \multirow[t]{2}{*}{ ICRG IP } & -0.0051 & -0.0590 & 0.0150 & -0.0073 \\
\hline & 0.0057 & 0.0469 & 0.0365 & 0.0414 \\
\hline \multirow[t]{2}{*}{ ICRG L\&O } & $0.0808^{* *}$ & $0.3373^{* *}$ & $-0.1590 * *$ & -0.0049 \\
\hline & 0.0147 & 0.0869 & 0.0642 & 0.0782 \\
\hline \multirow[t]{2}{*}{ ICRG BQ } & $0.0237^{*}$ & $0.5210 * *$ & $-0.6683 * *$ & $0.7487^{* *}$ \\
\hline & 0.0121 & 0.0974 & 0.0642 & 0.0999 \\
\hline \multirow[t]{2}{*}{ Constant } & $-4.0501 * *$ & $13.6018 * *$ & $-21.0604 * *$ & $30.6766^{* *}$ \\
\hline & 0.9594 & 3.4494 & 2.2054 & 3.1426 \\
\hline Mean of dependent variable & 0.1100 & 1.2590 & 2.7060 & 1.8930 \\
\hline SD of dependent variable & 0.1920 & 7.0734 & 9.4690 & 8.4970 \\
\hline SSR & 5436.2694 & 193603.2190 & 139309.6928 & 169427.6654 \\
\hline SE of Regression & 2.6420 & 15.3438 & 11.1961 & 13.2202 \\
\hline
\end{tabular}




$\begin{array}{lllll}\text { Variance of residuals } & 5.6246 & 205.5028 & 142.7258 & 176.2240 \\ \text { R-Squared } & 0.2190 & 0.1060 & 0.3010 & 0.1043 \\ \text { Serial correlation }(\mathrm{p})^{[1]} & 2.042 & 1.964 & 1.602 & 0.998 \\ & (0.153) & (0.161) & (0.206) & (0.318) \\ \text { Observations } & 602 & 602 & 602 & 602\end{array}$

${ }^{1}$ This is based on the Wooldridge (2002) test, see Wooldridge (2002) pp. 194-202 One-tailed tests: $p<0.10 ;{ }^{*} p<0.05 ;{ }^{* *} p<0.01 ;{ }^{* * *} p<0.001$ 
Table 2: 3SLS Results with Institution Interaction Terms

\begin{tabular}{|c|c|c|c|c|}
\hline Model 2: 3SLS Interactions & $\begin{array}{l}\text { Growth } \\
\text { Equation }\end{array}$ & $\begin{array}{l}\text { FDI } \\
\text { Equation }\end{array}$ & $\begin{array}{l}\text { ODA } \\
\text { Equation }\end{array}$ & $\begin{array}{l}\text { Remittance } \\
\text { Equation }\end{array}$ \\
\hline Dependent Variable & GDPpc Growth & FDI \%GDP & ODA \%GDP & REM \%GDP \\
\hline \multirow[t]{2}{*}{ Lagged dependent variable } & $0.2048 * *$ & $0.2860 * *$ & $-0.1390 * *$ & $0.4421 * *$ \\
\hline & 0.0061 & 0.0352 & 0.0510 & -0.0504 \\
\hline \multirow[t]{2}{*}{ GCF } & $0.0721 * *$ & & & \\
\hline & 0.0145 & & & \\
\hline \multirow[t]{2}{*}{ GDP per capita Growth } & & $5.7985^{* *}$ & $7.1461^{* *}$ & $-7.4310^{* *}$ \\
\hline & & 1.5226 & 1.6083 & 1.9959 \\
\hline \multirow[t]{2}{*}{ FDI \% GDP } & $0.1318^{* *}$ & & $-1.1796 * *$ & $1.3334 * *$ \\
\hline & 0.0258 & & 0.0706 & 0.0715 \\
\hline \multirow[t]{2}{*}{ ODA \% GDP } & $-0.1319 * *$ & $-0.6031 * *$ & & $0.9935 * *$ \\
\hline & 0.0114 & 0.0546 & & 0.0400 \\
\hline \multirow[t]{2}{*}{ REM \% GDP } & $0.1148 * *$ & $0.5014 * *$ & $0.9958 * *$ & \\
\hline & 0.0537 & 0.0331 & 0.0312 & \\
\hline \multirow[t]{2}{*}{ Trade \% GDP } & $0.1607 * *$ & $0.7501^{* *}$ & $1.1110^{* *}$ & $-1.1158 * *$ \\
\hline & 0.0275 & 0.1456 & 0.2142 & 0.2280 \\
\hline \multirow[t]{2}{*}{ Human Capital } & 0.0141 & $0.0927 * *$ & & \\
\hline & 0.0198 & 0.1282 & & \\
\hline \multirow[t]{2}{*}{ Population Growth } & $0.0953^{* *}$ & $-0.6652 * *$ & $-0.7794 * *$ & $0.9040^{* *}$ \\
\hline & 0.0257 & 0.1182 & 0.2032 & 0.2151 \\
\hline \multirow[t]{2}{*}{ Inflation } & $-0.0001 * *$ & -0.0025 & -0.0239 & 0.02484 \\
\hline & 0.0000 & 0.0747 & 0.0277 & 0.02896 \\
\hline \multirow[t]{2}{*}{ Landlocked } & -0.0704 & 0.4218 & 0.7207 & -0.6635 \\
\hline & 0.0413 & 0.2689 & 0.4515 & 0.4367 \\
\hline \multirow[t]{2}{*}{ ASIA } & $0.1768^{* *}$ & $1.0300^{* *}$ & $-1.6280 * *$ & $1.7296 * *$ \\
\hline & 0.0425 & 0.2372 & 0.3194 & 0.3063 \\
\hline \multirow[t]{2}{*}{ LA \& CAR } & $0.3317^{* *}$ & -1.2799 & -2.3488 & $2.1479 * *$ \\
\hline & 0.0752 & 0.2748 & 0.4462 & 0.4360 \\
\hline \multirow[t]{2}{*}{ SSA } & $0.1637 * *$ & $-0.8817 * *$ & $-1.2921 * *$ & $1.3784^{* *}$ \\
\hline & 0.0754 & 0.3554 & 0.6126 & 0.5884 \\
\hline \multirow[t]{2}{*}{ ICRG IP } & $-0.0351 * *$ & $0.1275^{* *}$ & $0.1774^{* *}$ & $-0.1784 * *$ \\
\hline & 0.0087 & 0.0511 & 0.0869 & 0.0848 \\
\hline \multirow[t]{2}{*}{ ICRG L\&O } & -0.0144 & 0.1045 & 0.1427 & -0.1588 \\
\hline & 0.0113 & 0.0715 & 0.0992 & 0.1045 \\
\hline \multirow[t]{2}{*}{ ICRG BQ } & $0.1086^{* *}$ & $-0.4702 * *$ & $-0.8732 * *$ & $0.8397 * *$ \\
\hline & 0.0219 & 0.1110 & 0.1826 & 0.1603 \\
\hline \multirow[t]{2}{*}{ ICRG IP $\times$ FDI } & $0.0401^{* *}$ & & & \\
\hline & 0.0043 & & & \\
\hline \multirow[t]{2}{*}{ ICRG L\&O × REM } & $0.0018 * *$ & & & \\
\hline & 0.0004 & & & \\
\hline \multirow[t]{2}{*}{$\mathrm{ICRG} \mathrm{BQ} \times \mathrm{ODA}$} & $0.0029 * *$ & & & \\
\hline & 0.0003 & & & \\
\hline \multirow[t]{2}{*}{ Constant } & -6.4024 & 36.6321 & 64.5242 & -57.6270 \\
\hline & 1.0809 & 4.2312 & 6.7759 & 6.0474 \\
\hline
\end{tabular}




\begin{tabular}{lllll} 
Mean of dependent variable & 0.1068 & 1.2305 & 1.7483 & 2.0067 \\
SD of dependent variable & 0.1782 & 6.5623 & 9.1497 & 8.2609 \\
SSR & 122.2028 & 343.4628 & 952.9843 & 830.0939 \\
SE of Regression & 4.0371 & 17.9224 & 31.5369 & 31.0581 \\
Variance of residuals & 15.9028 & 398.0704 & 1029.9334 & 907.0578 \\
R-Squared & 0.3101 & 0.2871 & 0.2578 & 0.1941 \\
Serial correlation (p) & 1.915 & 2.084 & 1.787 & 0.951 \\
& $(0.166)$ & $(0.149)$ & $(0.181)$ & $(0.329)$ \\
Observations & 602 & 602 & 602 & 602 \\
\hline
\end{tabular}

One-tailed tests: $p<0.10 ;{ }^{*} p<0.05 ;{ }^{* *} p<0.01 ;{ }^{* * *} p<0.001$ 
Table 3: 3SLS 5-Year Averages

\begin{tabular}{|c|c|c|c|c|}
\hline Model 3SLS 5-Year Averages & $\begin{array}{l}\text { Growth } \\
\text { Equation }\end{array}$ & $\begin{array}{l}\text { FDI } \\
\text { Equation }\end{array}$ & $\begin{array}{l}\text { ODA } \\
\text { Equation }\end{array}$ & $\begin{array}{l}\text { Remittance } \\
\text { Equation }\end{array}$ \\
\hline Dependent Variable & GDPpc Growth & FDI \%GDP & ODA \%GDP & REM \%GDP \\
\hline \multirow[t]{2}{*}{ Lagged dependent variable } & $0.2323 * *$ & $0.2523^{* *}$ & $-0.1580 * *$ & $0.4325 * *$ \\
\hline & 0.0061 & 0.0324 & 0.0375 & -0.0395 \\
\hline \multirow[t]{2}{*}{ GCF } & $0.0731 * *$ & & & \\
\hline & 0.0197 & & & \\
\hline \multirow[t]{2}{*}{ GDP per capita Growth } & & $5.2136^{* *}$ & $7.2318^{* *}$ & $-9.2537 * *$ \\
\hline & & 1.8831 & 1.5077 & 2.1662 \\
\hline \multirow[t]{2}{*}{ FDI \% GDP } & $0.1026^{* *}$ & & $-1.2171^{* *}$ & $1.2841^{* *}$ \\
\hline & 0.0269 & & 0.0801 & 0.0644 \\
\hline \multirow[t]{2}{*}{ ODA \% GDP } & $-0.1271 * *$ & $-0.4832 * *$ & & $1.2474^{* *}$ \\
\hline & 0.0119 & 0.0613 & & 0.0369 \\
\hline \multirow[t]{2}{*}{ REM \% GDP } & 0.0972 & 0.5103 & $0.8243^{* *}$ & \\
\hline & 0.0679 & 0.0358 & 0.0350 & \\
\hline \multirow[t]{2}{*}{ Trade \% GDP } & $0.1485^{* *}$ & $0.6733^{* *}$ & $0.9049 * *$ & $-1.2657 * *$ \\
\hline & 0.0289 & 0.1260 & 0.2102 & 0.2461 \\
\hline \multirow[t]{2}{*}{ Human Capital } & $0.0112 * *$ & $0.8190 * *$ & & \\
\hline & 0.0026 & 0.1409 & & \\
\hline \multirow{2}{*}{ Population Growth } & $0.0941^{* *}$ & $-0.7874 * *$ & $-1.0104 * *$ & $0.7112^{* *}$ \\
\hline & 0.0217 & 0.1301 & 0.2739 & 0.2327 \\
\hline \multirow[t]{2}{*}{ Inflation } & $-0.0004 * *$ & $-2.7668 * *$ & $-2.5112 * *$ & 2.7940 \\
\hline & 0.0001 & 0.9882 & 1.1790 & 1.6848 \\
\hline \multirow[t]{2}{*}{ Landlocked } & -0.0682 & 0.5533 & $0.8980 * *$ & -0.6323 \\
\hline & 0.0495 & 0.3254 & 0.3741 & 0.3955 \\
\hline \multirow[t]{2}{*}{ ASIA } & $0.2009 * *$ & $1.1925^{* *}$ & $-2.0512 * *$ & $2.0697 * *$ \\
\hline & 0.0354 & 0.2758 & 0.3699 & 0.2858 \\
\hline \multirow[t]{2}{*}{ LA \& CAR } & $0.3618^{* *}$ & $-1.6379 * *$ & $-3.1552 * *$ & $2.3519 * *$ \\
\hline & 0.0560 & 0.4070 & 0.4125 & 0.4477 \\
\hline \multirow[t]{2}{*}{ SSA } & 0.1625 & $-0.8172^{*}$ & -1.3845 & $1.6227^{* *}$ \\
\hline & 0.0850 & 0.4070 & 0.6496 & 0.5258 \\
\hline \multirow[t]{2}{*}{ ICRG IP } & $-0.0354^{* *}$ & $0.1346^{* *}$ & 0.1494 & $-0.2327 * *$ \\
\hline & 0.0102 & 0.0580 & 0.0910 & 0.0909 \\
\hline \multirow[t]{2}{*}{ ICRG L\&O } & -0.0114 & 0.0818 & $0.1895 * *$ & -0.1682 \\
\hline & 0.0130 & 0.0663 & 0.0820 & 0.1007 \\
\hline \multirow[t]{2}{*}{ ICRG BQ } & $0.1490 * *$ & $-0.4081 * *$ & $-0.8665 * *$ & $0.6461 * *$ \\
\hline & 0.0234 & 0.1222 & 0.1981 & 0.1404 \\
\hline \multirow[t]{2}{*}{ ICRG IP $\times$ FDI } & $0.0367 * *$ & & & \\
\hline & 0.0037 & & & \\
\hline \multirow[t]{2}{*}{ ICRG L\&O $\times$ REM } & $0.0018 * *$ & & & \\
\hline & 0.0007 & & & \\
\hline \multirow[t]{2}{*}{ ICRG BQ $\times$ ODA } & $0.0030 * *$ & & & \\
\hline & 0.0011 & & & \\
\hline
\end{tabular}




\begin{tabular}{lllll} 
Constant & $-6.8141^{* *}$ & $40.8187^{* *}$ & $49.5425^{* *}$ & $-76.0658^{* *}$ \\
& 0.9221 & 3.9109 & 6.1345 & 6.4879 \\
\hline Mean of dependent variable & 0.1103 & 1.2802 & 1.9101 & 1.8627 \\
SD of dependent variable & 0.0540 & 1.9455 & 3.0443 & 2.6860 \\
SSR & 25.6545 & 68.7525 & 161.3098 & 165.1560 \\
SE of Regression & 0.1238 & 0.6417 & 0.9097 & 0.9754 \\
Variance of residuals & 2.9568 & 70.1376 & 174.7245 & 209.2735 \\
R-Squared & 0.3724 & 0.2996 & 0.3175 & 0.2363 \\
Serial correlation (p) & 1.036 & 1.447 & 1.059 & 0.779 \\
& $(0.309)$ & $(0.229)$ & $(0.303)$ & $(0.377)$ \\
Observations & 120 & 120 & 120 & 120 \\
\hline
\end{tabular}

One-tailed tests: $p<0.10 ;{ }^{*} p<0.05 ;{ }^{* *} p<0.01 ;{ }^{* * *} p<0.001$ 
Appendix

Table A1: Descriptive Statistics

\begin{tabular}{llllll}
\hline Variable & Observations & Mean & Std. Dev. & Min & Max \\
\hline GDPpc Growth & 3121 & 1.789 & 6.472 & -50.490 & 90.070 \\
In Initial GDP & 2760 & 22.042 & 2.067 & 17.164 & 26.766 \\
ln GCF & 2909 & 3.050 & 0.431 & 0.565 & 4.733 \\
ln FDI \% GDP & 2780 & 0.379 & 1.925 & -13.279 & 5.972 \\
ln ODA \% GDP & 2908 & 0.983 & 2.090 & -9.234 & 5.488 \\
ln REM \% GDP & 2227 & 0.434 & 1.790 & -4.605 & 5.551 \\
ln REM × HDI & 2227 & 0.381 & 1.641 & -4.605 & 5.551 \\
ln Trade \% GDP & 2993 & 4.269 & 0.604 & 0.425 & 6.137 \\
ln Human Capital & 1823 & 1.299 & 0.645 & -0.994 & 2.348 \\
Population Growth & 3452 & 1.980 & 1.602 & -44.410 & 17.360 \\
Inflation & 2688 & 59.541 & 739.164 & -17.640 & 24411.030 \\
Landlocked & 3528 & 0.184 & 0.387 & 0 & 1 \\
ASIA & 3528 & 0.293 & 0.455 & 0 & 1 \\
LA \& CAR & 3528 & 0.163 & 0.370 & 0 & 1 \\
SSA & 3528 & 0.293 & 0.455 & 0 & 1 \\
ICRG IP & 2185 & 6.436 & 2.297 & 0 & 12 \\
ICRG L\&O & 2185 & 3.125 & 1.290 & 0 & 6 \\
ICRG BQ & 2185 & 1.668 & 0.960 & 0 & 4 \\
\hline
\end{tabular}


Table A2: Variable Correlations

\begin{tabular}{|c|c|c|c|c|c|c|c|c|c|c|c|c|c|c|c|c|c|}
\hline \multicolumn{2}{|c|}{ Variable } & 1 & 2 & 3 & 4 & 5 & 6 & 7 & 8 & 9 & 10 & 11 & 12 & 13 & 14 & 15 & 16 \\
\hline 1 & ln Initial GDP & 1.000 & & & & & & & & & & & & & & & \\
\hline 2 & $\ln \mathrm{GCF}$ & 0.180 & 1.000 & & & & & & & & & & & & & & \\
\hline 3 & $\ln$ FDI \% GDP & -0.114 & 0.178 & 1.000 & & & & & & & & & & & & & \\
\hline 4 & $\ln \mathrm{ODA} \% \mathrm{GDP}$ & -0.760 & -0.223 & -0.074 & 1.000 & & & & & & & & & & & & \\
\hline 5 & ln REM \% GDP & -0.146 & 0.130 & 0.052 & 0.214 & 1.000 & & & & & & & & & & & \\
\hline 6 & ln REM × HDI & -0.159 & 0.128 & 0.051 & 0.213 & 0.957 & 1.000 & & & & & & & & & & \\
\hline 7 & ln Human Capital & 0.346 & 0.287 & 0.298 & -0.574 & -0.043 & -0.003 & 1.000 & & & & & & & & & \\
\hline 8 & Population Growth & -0.316 & -0.272 & -0.254 & 0.476 & -0.064 & -0.085 & -0.502 & 1.000 & & & & & & & & \\
\hline 9 & Inflation & 0.048 & -0.023 & -0.076 & -0.036 & -0.095 & -0.098 & 0.021 & -0.008 & 1.000 & & & & & & & \\
\hline 10 & Landlocked & -0.311 & -0.107 & 0.014 & 0.293 & -0.168 & -0.144 & -0.263 & 0.263 & 0.053 & 1.000 & & & & & & \\
\hline 11 & ASIA & 0.429 & 0.305 & -0.139 & -0.175 & 0.146 & 0.160 & 0.210 & -0.075 & -0.046 & -0.238 & 1.000 & & & & & \\
\hline 12 & LA \& CAR & 0.128 & -0.139 & 0.187 & -0.290 & -0.051 & -0.044 & 0.351 & -0.252 & 0.100 & -0.038 & -0.431 & 1.000 & & & & \\
\hline 13 & SSA & -0.494 & -0.234 & -0.058 & 0.523 & -0.167 & -0.196 & -0.519 & 0.480 & -0.040 & 0.423 & -0.337 & -0.415 & 1.000 & & & \\
\hline 14 & ICRG IP & -0.027 & 0.266 & 0.386 & -0.226 & 0.096 & 0.114 & 0.284 & -0.211 & -0.114 & 0.114 & -0.054 & 0.006 & 0.052 & 1.000 & & \\
\hline 15 & ICRG L\&O & 0.088 & 0.310 & 0.228 & -0.215 & -0.146 & -0.133 & 0.227 & -0.129 & -0.065 & 0.067 & 0.159 & -0.143 & -0.017 & 0.239 & 1.000 & \\
\hline 16 & ICRG BQ & 0.318 & 0.280 & 0.145 & -0.391 & -0.125 & -0.086 & 0.331 & -0.249 & -0.039 & -0.152 & 0.158 & -0.087 & -0.149 & 0.276 & 0.338 & 1.000 \\
\hline
\end{tabular}


Table A3: Single Equation GMM

\begin{tabular}{|c|c|c|c|c|}
\hline $\begin{array}{l}\text { Single Equation GMM with } \\
\text { Interactions }\end{array}$ & $\begin{array}{l}\text { Growth } \\
\text { Equation }\end{array}$ & $\begin{array}{l}\text { FDI } \\
\text { Equation }\end{array}$ & $\begin{array}{l}\text { ODA } \\
\text { Equation }\end{array}$ & $\begin{array}{l}\text { Remittance } \\
\text { Equation }\end{array}$ \\
\hline Dependent Variable & GDPpc Growth & FDI \%GDP & ODA \%GDP & REM \%GDP \\
\hline \multirow[t]{2}{*}{ Lagged dependent variable } & $0.2210 * *$ & $0.2772 * *$ & $-0.1523^{* *}$ & $0.4031^{* *}$ \\
\hline & 0.0058 & 0.0351 & 0.0414 & -0.0425 \\
\hline \multirow{2}{*}{ GCF } & $0.0514^{* *}$ & & & \\
\hline & 0.0226 & & & \\
\hline \multirow[t]{2}{*}{ GDPpc Growth } & & $8.0691 * *$ & $10.1192 * *$ & $-11.2128 * *$ \\
\hline & & 2.3141 & 2.3916 & 2.6477 \\
\hline \multirow[t]{2}{*}{ FDI \% GDP } & $0.2024 * *$ & & $-1.4680 * *$ & $1.6173^{* *}$ \\
\hline & 0.0071 & & 0.0860 & 0.1099 \\
\hline \multirow[t]{2}{*}{ ODA \% GDP } & $-0.2213^{* *}$ & $-0.7292 * *$ & & $1.3288 * *$ \\
\hline & 0.0086 & 0.0557 & & 0.0579 \\
\hline \multirow[t]{2}{*}{ REM \%GDP } & $0.1712^{* *}$ & $0.6013^{* *}$ & $1.2232^{* *}$ & \\
\hline & 0.0427 & 0.0386 & 0.0324 & \\
\hline \multirow[t]{2}{*}{ Human Capital } & 0.0184 & 0.1072 & & \\
\hline & 0.0200 & 0.1950 & & \\
\hline \multirow[t]{2}{*}{ Population Growth } & $0.1193 * *$ & $-0.7411 * *$ & $-1.1289 * *$ & $1.3345^{* *}$ \\
\hline & 0.0286 & 0.1779 & 0.2630 & 0.2990 \\
\hline \multirow[t]{2}{*}{ Inflation } & $-0.0003 * *$ & $-2.7220 * *$ & $-2.9637 * *$ & $3.7506^{* *}$ \\
\hline & 0.0001 & 0.9283 & 1.4973 & 1.3007 \\
\hline \multirow[t]{2}{*}{ Landlocked } & -0.0823 & 0.5220 & 0.9629 & -0.8788 \\
\hline & 0.0633 & 0.3131 & 0.5548 & 0.4854 \\
\hline \multirow[t]{2}{*}{ ASIA } & $0.2068 * *$ & 1.2876 & $-2.0765^{* *}$ & $2.1278 * *$ \\
\hline & 0.0461 & 0.2773 & 0.4092 & 0.4262 \\
\hline \multirow[t]{2}{*}{ LA \& CAR } & $0.3835^{* *}$ & $-1.8197^{* *}$ & $-2.8822^{* *}$ & $2.7980 * *$ \\
\hline & 0.0908 & 0.3977 & 0.6024 & 0.5219 \\
\hline \multirow[t]{2}{*}{ SSA } & $0.2404^{* *}$ & $-1.2650^{* *}$ & $-1.5733^{* *}$ & $1.7783^{* *}$ \\
\hline & 0.1080 & 0.4035 & 0.6246 & 0.6888 \\
\hline \multirow[t]{2}{*}{ ICRG IP } & $-0.0361 * *$ & $0.1727 * *$ & $0.2452^{* *}$ & -0.2034 \\
\hline & 0.0133 & 0.0679 & 0.0874 & 0.1059 \\
\hline \multirow[t]{2}{*}{ ICRG L\&O } & -0.0192 & 0.1421 & 0.1993 & -0.1576 \\
\hline & 0.0148 & 0.0952 & 0.1343 & 0.1257 \\
\hline \multirow[t]{2}{*}{ ICRG BQ } & $0.1203^{* *}$ & $-0.7153^{* *}$ & $-1.1677 * *$ & $0.8914^{* *}$ \\
\hline & 0.0253 & 0.1379 & 0.1987 & 0.2018 \\
\hline \multirow[t]{2}{*}{ ICRG IP $\times$ FDI } & $0.0469 * *$ & & & \\
\hline & 0.0053 & & & \\
\hline \multirow[t]{2}{*}{ ICRG L\&O × REM } & $0.0019 * *$ & & & \\
\hline & 0.0004 & & & \\
\hline \multirow[t]{2}{*}{ ICRG BQ × ODA } & $0.0029 * *$ & & & \\
\hline & 0.0003 & & & \\
\hline \multirow[t]{2}{*}{ Constant } & $-9.7656 * *$ & $42.7644 * *$ & $72.7678 * *$ & $-81.6580 * *$ \\
\hline & 1.5318 & 6.2377 & 7.2572 & 7.6109 \\
\hline $\mathrm{N}$ & 574.0000 & 574.0000 & 574.0000 & 574.0000 \\
\hline Sargan (p value) & 0.2334 & 0.0983 & 0.3023 & 0.1918 \\
\hline
\end{tabular}




$\begin{array}{lllll}\text { AR(1) (p value) } & 0.8473 & 0.7320 & 1.2007 & 0.8063 \\ \text { AR(2) (p value) } & 2.5697 & 2.6826 & 1.6975 & 2.1950 \\ \operatorname{corr}(Y, \hat{Y}) & 0.1236 & 0.0944 & 0.1070 & 0.1319\end{array}$

One-tailed tests: $p<0.10 ;{ }^{*} p<0.05 ;{ }^{* *} p<0.01 ;{ }^{* * *} p<0.001$ 


\footnotetext{
${ }^{\mathrm{i}}$ Where $(1-\lambda)$ is the share of remittances for domestic consumption.

ii This variable is included to determine whether remittances have a greater impact on countries with a higher level of Human Development. To calculate this variable we split the sample into two. Countries included in the category 'Medium Human Development' according to the World Bank Human Development Report (2006) are coded with a 1. Countries in the category 'Low Human Development' are coded with a 0. This variable is then interacted with Migrant Remittances. It is important to point out that the HDI score does not change overtime we just use the 2006 data.

iii For both equations the random effects estimator rejects the restriction of fixed effects.

${ }^{\text {iv }}$ With panel data, there is also the concern that the standard errors on some coefficients are biased downwards due to correlation across years. The standard "clustering" algorithm is employed to allow for this - see for example Petersen (2006). However, in practice the panels used here are relatively unbalanced, such that the difference between the clustered and unclustered standard errors is small.

${ }^{\mathrm{v}}$ We also ran a number of Chow-type tests for a more restricted model excluding the regional dummies to test for differences between continents, or between levels of development. These however did not yield any significant differences between the various subsamples. It should be stressed that given the number of countries, and the number of coefficients for the full simultaneous model, there are few degrees of freedom even if we divide into only three subsamples.

${ }^{\mathrm{vi}}$ The last period is only 4 years.

vii The data available in the WDI for the variable migrant remittances is entitled 'workers remittances, compensation of employees, and migrant transfers'. Giuliano and Ruiz-Arranz (2009) use this measure and find that for some countries the inclusion of 'compensation of employees' (which is often payments to embassy staff, or the like) can bias the remittance data. We do not make these adjustments as they do acknowledge that the correlation pre and post adjustment remains at 0.92. In addition, we acknowledge that remittances through informal channels may be substantial.

viii The start data of 1984 is chosen because the ICRG data begins in this year.

${ }^{\text {ix }}$ Table A3 in the Appendix produces results for single-equation estimates for each of the 4 equations. These estimates are derived using GMM, but clearly show that the 3SLS systems approach yields more reliable results.
} 